\title{
SURVEY OF THE NEUROLOGICAL EVOLUTION OF 300 SPINAL CORD INJURIES SEEN WITHIN 24 HOURS AFTER INJURY
}

\author{
By R. Philippi, M.D., W. Kuhn, M.D., M.D.D., ^ G. A. ZäCH, M.D., ${ }^{1}$ \\ D. Jacob-Chia, M.D., P. Dollfus, M.D. ${ }^{2}$ and J. P. Molé, M.D. ${ }^{3}$ \\ ${ }^{1}$ Swiss Paraplegic Centre, Basle, Switzerland; ${ }^{2}$ Centre de Réadaptation, Mulhouse, France; \\ ${ }^{3}$ Hôpital Louis Pasteur, Colmar, France
}

\begin{abstract}
A grouped Franco-Swiss study on 300 cases of spinal cord injury gives an overall view of the neurological evolution of the spinal cord injuries or cauda equina lesions. The importance of initial and repeated examinations is stressed. Sensory sparing distant to the lesion is of great importance, especially that of pain. A great number of patients showing neurological progress was observed at the end of the first month and at the beginning of the following three months. The influence of steroids is tentatively discussed. No complications due to this therapy have been observed on the condition that their use is very limited in time. Statistically speaking, there has been no difference of evolution in the two groups, the majority having been treated orthopedically.
\end{abstract}

Key words: Neurological recovery; Spinal cord injury; Tetraplegia; Paraplegia; Corticosteroid therapy.

\section{Introduction}

Although several attempts have been made in the literature to classify, at least clinically, the evolution of the neurological damage on admission and discharge (Frankel et al., 1969; Michaelis, 1969; Frankel et al., 1973; Paeslack et al., 1973; Burke \& Murray, I976; Zäch et al., I976; Molé, 1977; Bracken et al., 1978; Young \& Dexter, 1978), it seemed important for us to try and adapt such a classification method considering the spinal cord or cauda equina lesions from the first examination onwards within the first 24 hours after injury, after 48 hours, during the period of I month, then the following 3 months and finally on discharge; this according to the length of stay in the rehabilitation centres (about 6 months for paraplegics, 9 to 12 months for tetraplegics). This was only to try and get an impression, and not more than an impression, as to the possible general chronological evolution of such lesions, knowing the great individuality of spinal cord lesions where so many factors are involved: i.e. the circumstances of the accident, the actual forces involved at the vertebral level during the accident as well as other factors responsible for the damage and the immediate lesion of the spine or its roots and possibly the secondary insult, either chemical or vascular (haemorrhagic central cord necrosis, oedema, etc.), considering as well many other parameters which are more or less known at the time of admission.

Another aspect we wanted to study was the neurological evaluation according to the medical therapy used within the first 24 hours and onwards for one week, as in the Colmar-Mulhouse study and ro days after injury, as in the Basle study (Tables IIA, IIB and IIC). Although steroids are still very much discussed, even as far as animal experimentation is concerned, no real report as to their clinical

* Address for reprints Dr W. Kuhn, Schweizerisches Paraplegikerzentrum, Im Burgfelderhof 40, $\mathrm{CH}-4055$ Basel, Switzerland. 
efficiency has yet been given. We thought it was interesting to investigate this aspect as the Colmar-Mulhouse group was treated without steroids before 1975 and with steroids after-but for a shorter length of time than in Basle.

The population concerned in the Basle study are all those admitted either directly from the site of injury, or transferred from hospitals. The Swiss Paraplegic Centre (SPC) serves approximately a general population of five million people and is concerned in this study with the admissions (within 24 hours after injury) for the years 1976 , 1977 and 1978 .

The Colmar-Mulhouse group study is concerned with the Io-year period from 1978 backwards and considers patients seen after the accident by one of the spinal cord injury consultants, mainly in the hospital Louis Pasteur of Colmar, either in the traumatology unit, or in one of the two neurosurgical units. A smaller number of patients was seen at the Mulhouse hospital or referred directly by local hospitals of the region to the spinal cord injury unit of the rehabilitation centre of Mulhouse. A general population of approximately I,200,000 can be estimated in this group.

\section{Methods}

Table I considers operated and non-operated patients.

Table IIA describes the treatment as used routinely in Basle (Zäch et al., I976).

Table IIB describes the medical treatment given in Colmar and Mulhouse before 1975 .

Table IIC shows the medical treatment in Colmar and Mulhouse after 1975 described by Molé (1977). One can notice the difference between the two treatments although the anticoagulant therapy has been used; Calciparin ${ }^{\circledR}$ has been started in 1973 and used continuously since 1975 and discontinuing anti-

TABLE I

Treatment of vertebral injury

\begin{tabular}{|c|c|c|}
\hline $\begin{array}{l}\text { Orthopaedic-conservative reduction: } \\
\text { Open reductions, laminectomies, stabilisations: }\end{array}$ & $\begin{array}{r}273 \\
9^{\star} \\
18 \dagger\end{array}$ & $\begin{array}{r}(91 \%) \\
(3 \%) \\
(6 \%)\end{array}$ \\
\hline & 300 & $(100 \%)$ \\
\hline
\end{tabular}

* Within first week; $\dagger$ after first week.

TABle II A

Medical treatment, Basle

Dexamethasone

Rheomacrodex $40^{\circledR}$

Mannitol 20\%

Hydergine ${ }^{\circledR}$

Heparin

Liquamar ${ }^{\circledR}$

Maaloxan ${ }^{\circledR}$

Cimetex $^{\circledR}$
$0.5 \mathrm{mg} / \mathrm{kg}$ first 4 days, then daily reduced $10 \%$ $500 \mathrm{ml}$ daily for one week

In special cases only

$0.33 \mathrm{mg}$ every 8 hours for 3 months

5000 i.u. every 12 hours s.c. for 3 weeks

After 3 weeks

4 times $20 \mathrm{ml}$ daily

In special cases, since 1977 
TABLE IIB

Medical treatment, Colmar-Mulhouse before I975

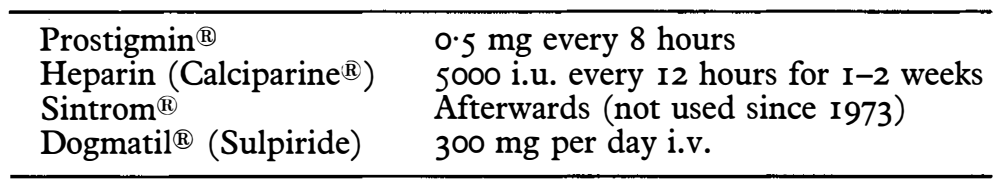

TABLE IIC

Medical treatment, Colmar-Mulhouse after 1975

Solumedrol ${ }^{\circledR}$

Heparin (Calciparine ${ }^{\circledR}$ )

Dogmatil ${ }^{\circledR}$ (Sulpiride)
$240 \mathrm{mg}$ first 2 days, gradually reduced in 6 days $5000-7500$ i.u. s.c. 3 times daily $300 \mathrm{mg}$ per day i.v.

vitamin $\mathrm{K}$; Calciparin ${ }^{\circledR}$ is being used until the patient is up in his wheelchair and in active physiotherapy. Prostigmin ${ }^{\circledR}$ has been abandoned as giving no obvious results. Dogmatil ${ }^{\circledR}$ (Sulpiride) is used but without any specific conviction on its action. Concerning the medical treatment of Basle since 1977, Cimetex ${ }^{\circledR}$ (Cimetidine) was tried to avoid gastric ulcers.

Table III shows the parameters used according to the description of Hans Frankel. This system of studying the clinical evolution, although far from being perfect, was found practical to try and get an idea of the evolution according to the method described in the introduction.

Table IV gives the study of the three different cervical injury groups. One without cortisone, i.e. those admitted before 1975 (Colmar-Mulhouse) and in the same table in the upper corners those treated with steroids. The Basle group was treated from the start with steroids and the results are given on the right side, all the patients having received steroids and the treatment described above.

\section{TABLE III}

$\overline{\mathrm{A}}=$ 'Complete.' This means that the lesion was found to be complete both motor and sensory below the segmental level marked. If there was an alteration of level but the lesion remained complete below the new level, then the arrow would point up or down the 'complete' column.

B = 'Sensory Only.' This implies that there was some sensation present below the level of the lesion but that the motor paralysis was complete below that level. This column does not apply when there is a slight discrepancy between the motor and the sensory level but does apply to sacral sparing.

$\mathrm{C}=$ 'Motor Useless.' This implies that there was some motor power present below the lesion but it was of no practical use to the patient.

$\mathrm{D}=$ 'Motor Useful.' This implies that there was useful motor power present below the level of the lesion. Patients in this group could move the lower limbs and many could walk, with or without aids.

$\mathrm{E}=$ 'Recovery.' This implies that the patient was free of neurological symptoms, i.e. no weakness, no sensory loss, no sphincter disturbance. Abnormal reflexes may have been present.

From: Frankel, H. L., Hancock, D. O. \& Hyslop, G. (I969) 


\section{TABLE IV}

Cervical injuries

Colmar-Mulhouse

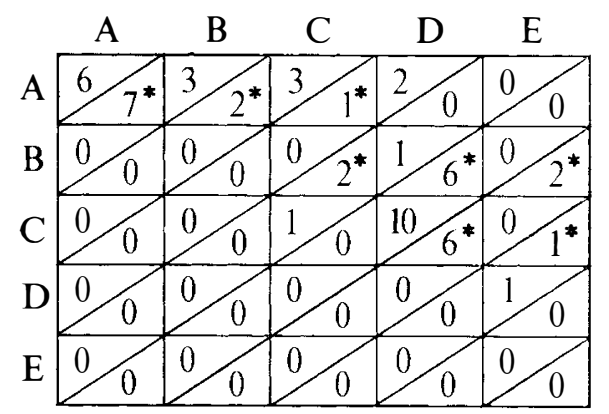

* Without cortisone

No change $7 \quad 26 \% \quad 7^{\star} \quad 26 \%$ Improved $20 \quad 74 \% \quad 20^{\star} \quad 74 \%$ Worsened

$\mathrm{N}$

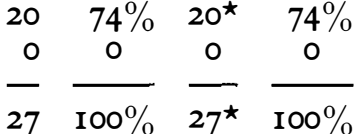

Basle

\begin{tabular}{l|c|c|c|c|c|}
\multicolumn{1}{c}{ A } & B & C & D & E \\
\cline { 2 - 6 } A & I3 & 9 & 0 & I & I \\
\hline B & O & I & 2 & 4 & 2 \\
\hline C & 0 & 0 & 0 & 8 & 3 \\
\hline D & O & 0 & 0 & 2 & 8 \\
\hline E & 0 & 0 & 0 & 0 & 0 \\
\hline
\end{tabular}

$\begin{array}{lrc}\text { No change } & 16 & 30 \% \\ \text { Improved } & 38 & 70 \% \\ \text { Worsened } & 0 & 0 \\ \text { N } & - & \text { 100\% }\end{array}$

Table $\mathrm{V}$ shows the study of the TI-Tio injuries. The results are given in a similar way, i.e. on the left, the Colmar-Mulhouse group with or without steroids and on the right, the Basle group, all results following the same method described previously. This method is also used in

\section{TABLE V}

\section{TI-Tıo injuries}

Colmar-Mulhouse

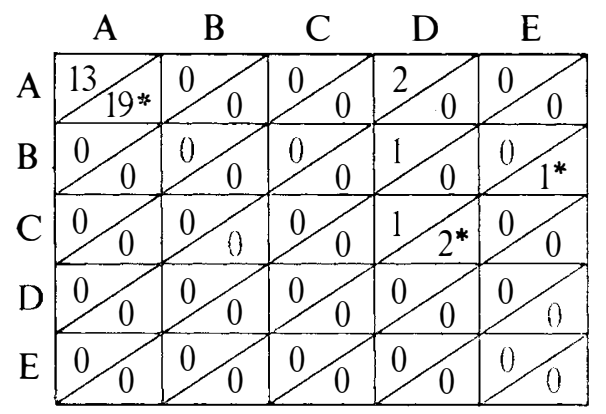

Basle

\begin{tabular}{|c|c|c|c|c|}
\hline A & B & C & $\mathrm{D}$ & $\mathrm{E}$ \\
\hline 24 & 5 & I & 0 & 0 \\
\hline B & I & 2 & 0 & 2 \\
\hline $\mathrm{C}$ & 0 & 0 & 0 & 2 \\
\hline D & 0 & 0 & 0 & 0 \\
\hline 0 & 0 & 0 & 0 & 0 \\
\hline
\end{tabular}

* Without cortisone

No change I3 $\quad 76 \%$ I9 $9^{\star} \quad 86 \%$

Improved $4 \quad 24 \% \quad 3^{\star} \quad 14 \%$

Worsened

$\mathrm{N}$

$\frac{0}{17} \frac{0}{100 \%} \frac{0}{22^{\star}} \frac{0}{100 \%}$
No change $\quad 25$

Improved I2

Worsened

$\mathrm{N}$

$$
\begin{aligned}
& 67 \% \\
& 33 \%
\end{aligned}
$$$$
\text { 37 } \quad \overline{100 \%}
$$ 


\section{TABLE VI}

\section{TII-TI2-LI injuries}

Colmar-Mulhouse

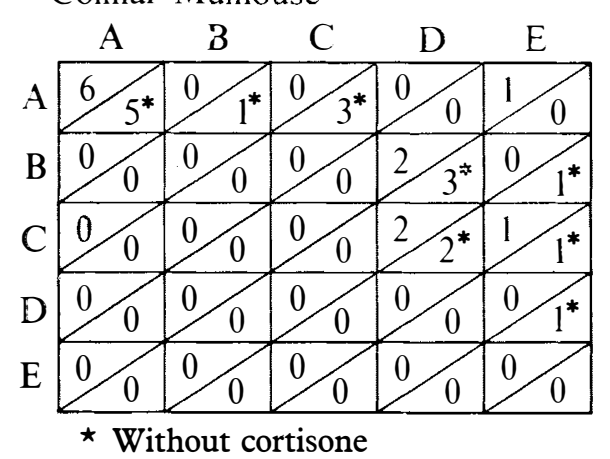

\begin{tabular}{lrrrr} 
No change & 6 & $50 \%$ & $5^{\star}$ & $30 \%$ \\
Improved & 6 & $50 \%$ & $12^{\star}$ & $70 \%$ \\
Worsened & 0 & 0 & 0 & 0 \\
\cline { 2 - 4 } N & I2 & $100 \%$ & I7* & $100 \%$
\end{tabular}
Basle

$\begin{array}{lllll}\text { A } & \text { B } & \text { C } & \text { D } & \text { E }\end{array}$

\begin{tabular}{|c|c|c|c|c|c|}
\hline $\mathrm{A}$ & $\mathrm{I} 2$ & 5 & 3 & 0 & 0 \\
\hline $\mathrm{B}$ & $\mathrm{O}$ & $\mathrm{3}$ & $\mathrm{I}$ & 3 & 5 \\
\hline $\mathrm{C}$ & $\mathrm{O}$ & $\mathrm{O}$ & 2 & 7 & 8 \\
\hline $\mathrm{D}$ & $\mathrm{O}$ & $\mathrm{O}$ & $\mathrm{O}$ & $\mathrm{I}$ & $\mathrm{I}$ \\
\hline $\mathrm{D}$ & $\mathrm{O}$ & $\mathrm{O}$ & $\mathrm{O}$ & $\mathrm{O}$ & $\mathrm{O}$ \\
\hline
\end{tabular}

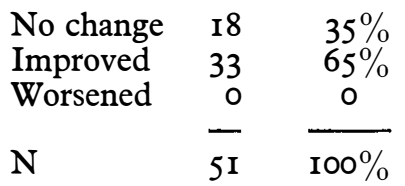

Table VI, which describes the TII, TI2 and LI injuries, as well as in

Table VII, describing the L2-L5 cauda equina lesions.

Table VIII gives the added number of cervical injuries of Colmar-Mulhouse and Basle, as well as

Table IX, the TI-TIo injuries, and

Table X, the TII, TI2 and LI injuries, and

Table XI, the L2-L5 injuries.

\section{TABLE VII}

\section{L2-L5 injuries}

Colmar-Mulhouse

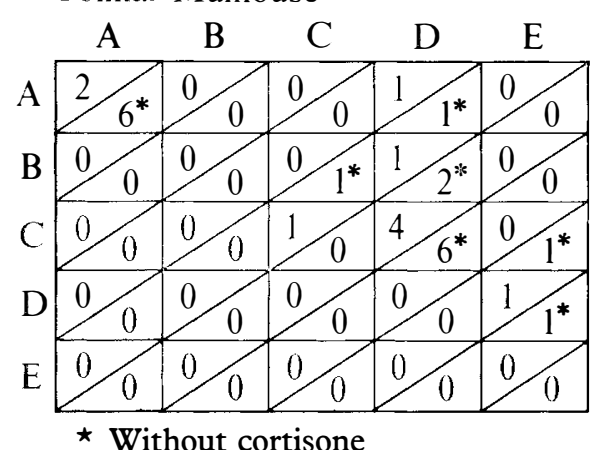

Without cortisone

No change $3 \quad 30 \% \quad 66^{\star} \quad 33 \%$

Improved $\quad 7 \quad 70 \% \quad 12^{\star} \quad 67 \%$

Worsened

$\mathrm{N}$
Basle

\begin{tabular}{|c|c|c|c|c|}
\hline A & B & C & D & $\mathrm{E}$ \\
\hline 0 & 0 & 0 & 0 & 0 \\
\hline 0 & 0 & 2 & 0 & 0 \\
\hline 0 & 0 & I & 2 & 3 \\
\hline 0 & 0 & 0 & 0 & 0 \\
\hline 0 & 0 & 0 & 0 & 0 \\
\hline
\end{tabular}

No change I $\quad 13 \%$

Improved $7 \quad 87 \%$

Worsened

$\mathrm{N}$

$\frac{0}{8} \quad \frac{0}{100 \%}$


On the other hand, we have used (to try and study the evolution in time) the same method as described in the introduction, i.e. the Frankel classification system, although not very adequately, studying the evolution from admission, after 24 hours, 48 hours, I month, 3 months and on discharge. This has given us an overall view of the evolution of the different categories involved but still a better method needs to be devised.

TABLE VIII

Cervical injuries

Colmar-Mulhouse + Basle

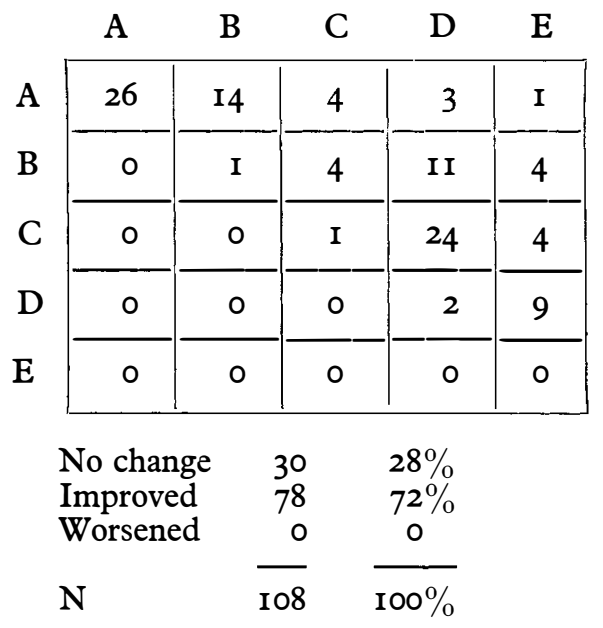

TABLE IX

Ti-Tıо injuries

Colmar-Mulhouse + Basle

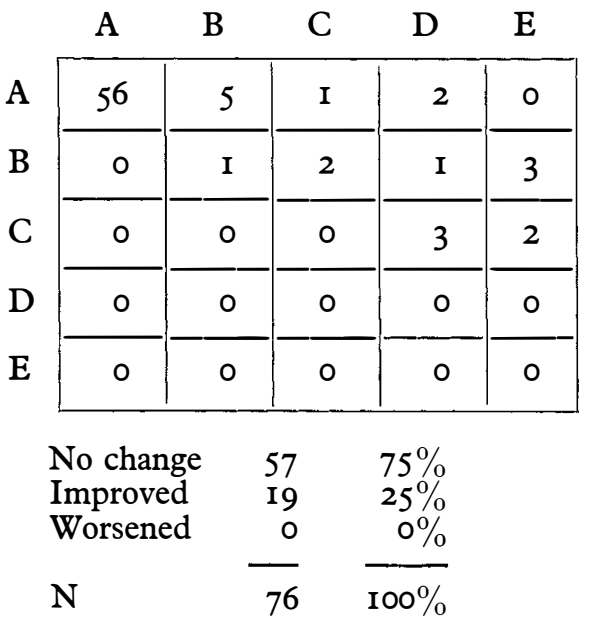


TABLE X

TII-TI2-Li injuries

Colmar-Mulhouse + Basle

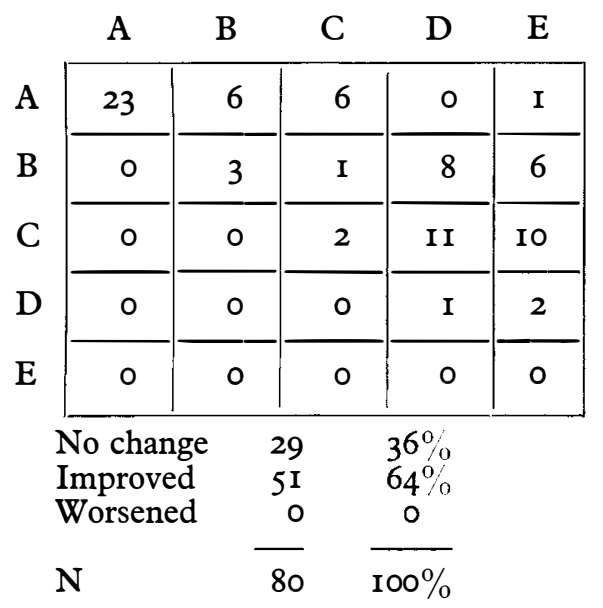

TABLE XI

$\mathrm{L}_{2}-\mathrm{L}_{5}$ injuries

Colmar-Mulhouse + Basle

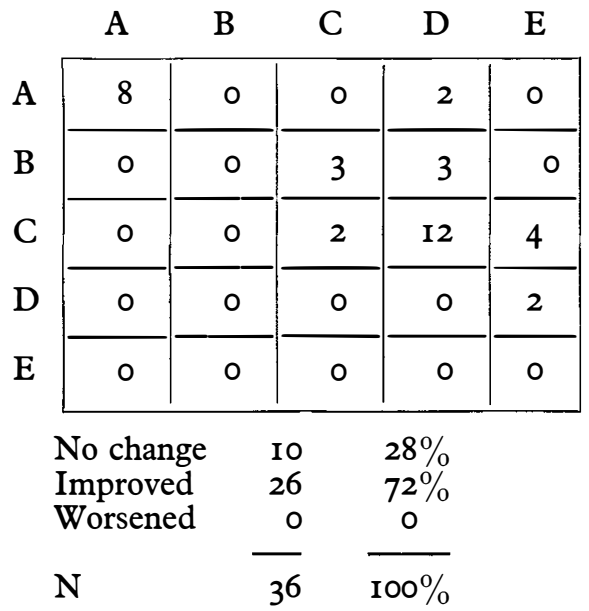

\section{Results}

(a) As far as the cervical injuries (Table IV) are concerned, there is no significant difference between the Basle and the Colmar-Mulhouse results, excepting perhaps in grade $\mathrm{D}$, which is, in fact, a very difficult category to classify in percentage. In the Colmar-Mulhouse group there is no change between the non-steroid and the steroid group.

(b) Concerning the TI-Tio injuries (Table V), the numbers are identical but there is a slight percentagewise improvement in the Swiss group and no 
statistical difference between those treated with or without cortisone in the Colmar-Mulhouse group.

(c) In the TII-LI group (Table VI) there is also no significant statistical difference between the two studies, although there are perhaps better results in the non-cortisone group.

(d) Concerning the L2-L5 injuries (Table VII), there are fewer cases reported in the Basle study, which makes it difficult to evaluate the two studies statistically. It must be mentioned that the transfer of cauda equina lesions is lower from the orthopaedic hospitals to a spinal cord injury centre, at least in this group.

(e) Considering the non-operated and the operated patients (Table I), one can see that in both series the percentage of operated patients is extremely low and operations were indicated in collaboration with the surgical teams on very specific indications. The majority of the patients were treated by orthopaedic conservative reduction (9I per cent).

\section{Discussion}

As far as the first neurological examination is concerned, certain difficulties must be outlined, i.e. the state of consciousness of the patient as well as the intensity of the hypovolemic shock and the importance of associated lesions. These difficulties have been studied in the literature (Dollfus, I973; Hardy, I973; Dollfus et al., 1974; Stauffer, 1975; Vlahovitch et al., 1975; Dollfus et al., 1976; Guttmann, I976; Hachen, I977; Vlahovitch et al., 1977; Chapelle, 1978). It must be mentioned that all these patients on both sides of the border were examined according to the teaching of Sir Ludwig Guttmann.

Concerning grade $\mathrm{A}$, it is very difficult to know if a patient is going to become either $\mathrm{B}, \mathrm{C}$ or $\mathrm{D}$ in the next few days. Concussion of the spinal cord can mask, in fact, for a few hours (even up to 2 days) the real neurological damage, at least in the very early stages. As for the evolution itself, patients estimated as being grade A or B in the first 24 hours become for those who have improved C or D after the fourth month and usually improving toward the second or third month. This applies equally to patients in the dorsal group. In the dorso-lumbar and lumbar group recovery seems to occur slightly earlier within the first month or between the first month and the 3-month period.

As far as sensation is concerned in grade $B$, attention should be made to the fact that sacral sparing for pain has a much better prognosis than when there is touch only.

In grade $\mathrm{D}$ of the dorsal group there are none registered either in the Swiss group or in the French group. This is probably due to the fact that this type of patient with few obvious symptoms (pain at the site of fracture is usually the main complaint on admission into the emergency room after the accident) is often transferred to a traumatology ward and considered as having no neurological signs. Only a very thorough neurological examination can detect such signs as some patchy diminishing of sensation. Sometimes these patients have a small and undiagnosed ileus or a short period of urinary retention. None of these patients examined in Colmar-Mulhouse were considered for study in this group and for similar reasons not transferred from orthopaedic hospitals to the Swiss Paraplegic Centre.

As for the operated and non-operated patients (Table I), the very low number of operated patients does not allow any statistical interpretation. All of them showed no signs of worsening. The indications for operation were very strict indeed. Their evolution was roughly similar to that of the non-operated cases. 
As regards the medical treatment, there seems to be no statistical difference between the non-steroid and steroid groups.

We think that it is of the utmost importance that the patient should be properly handled right from the beginning, with the fewest possible manipulations, either at the site of accident, or in the first hospital. Without doubt, more information of the public and the first--aid personnel should be encouraged. This would be the best prevention against further neural damage.

As far as reflex activity is concerned, it has no relevant prognosis value in the two studies. The conus reflexes must be studied extremely carefully, especially in the dorso-lumbar group, as the loss of these reflexes might indicate an aggravation of the neurological status. The same applies to the sensory sparing, especially that of pain (pinprick) in this area, according to the studies of Stauffer (1975) and Vlahovitch et al. (1975).

Concerning the different types of fracture in our study, there was no statistical difference between the type of fractures and the results of neurological status studied in the literature (Bedbrook, 1973; Frankel et al., 1973; Paeslack et al., 1973; Burke \& Murray, 1976; Guttmann, 1976). It is of the utmost importance that a proper, full neurological examination should be performed by a well-trained person and also that this neurological examination should be repeated several times during the first 48 hours.

The importance of proper care of these patients can never be overstressed as well as the orthopaedic immobilisation in good hands.

No significant changes have occurred under steroid therapy, but still, in the hope that in very few patients it can be active, we shall continue to use it as otherwise it has not proved to be dangerous, provided that it is used in a very limited lapse of time.

Perhaps another more sophisticated system of classification should be devised in the years to come, to enable us to get a better statistical view of the chronological evolution of the neurological progress.

\section{RÉSUMÉ}

Une étude groupée franco-suisse donne un aperçu de l'évolution neurologique des lésions médullaires ou médullo-radiculaires sur 300 cas. L'importance des examens initiaux, répétés est soulignée. L'épargne sensitive distale est d'une très grande importance. La majorité des progrès observés sur le plan neurologique se situe à la fin du premier mois et au début des trois mois suivants. L'influence des corticoïdes ne semble pas statistiquement significative. Aucune complication due aux stéroïdes n'a été observée, à condition que leur emploi soit très limité dans le temps. Par ailleurs aucune différence significative n'a été observée dans les deux groupes dont la majorité des cas a été traitée par la méthode orthopédique.

\section{ZUSAMMENFASSUNG}

Eine französisch-schweizerische Gruppenstudie über 300 Fälle von Rückenmarkverletzungen gibt eine Übersicht über die neurologische Entwicklung der Rückenmark- oder cauda-equina-Verletzungen. Die Bedeutung der ersten und wiederholten neurologischen Untersuchung wird betont. Die sensible Aussparung unterhalb der Läsion ist sehr wichtig, insbesondere die Schmerzempfindung. Am Ende des ersten Monats nach Trauma zeigt eine große Zahl von Patienten mit neurologischer Besserung. Ebenso zu Beginn der darauffolgenden drei Monate. Der Einfluß von Cortico-Steroiden wird diskutiert. Komplikationen seitens dieser Therapie wurden nicht beobachtet, unter der Bedingung, daß sie nur sehr kurz erfolgte. In den beiden Gruppen, die zuallermeist konservativ behandelt wurden $(91 \%)$, konnte kein statistisch relevanter Unterschied hinsichtlich neurologischer Entwicklung festgestellt werden. 


\section{REFERENCES}

BeDBrook, G. M. (1973). Compression, flexion and extension of the cervical spine with tetraplegia. Proc. I9th Veterans Adm. Spinal Cord Inj. Conf., Scottsdale, Arizona.

BRACKEN, M. B., WEBB, S. B. \& WAGNER, F. C. (I978). Classification of the severity of acute spinal cord injury: implications for management. Paraplegia, 15, 319-326.

BURKE, D. C. \& MURRAY, D. D. (I976). The management of thoracic and thoraco-lumbar injuries of the spine with neurological involvement. F. Bone ft. Surg., 58-B, 72-78.

Chapelle, P. A. (1978). Valeur sémiologique des syndromes lésionnels cérébro-spinal et végétatif: étude critique. Ann. Méd. phys., 21, 517-5I8.

Dollfus, P. (1973). Closed injuries of the dorsal and dorsi-lumbar spine and cord. Proc. 19th Veterans Adm. Spinal Cord Inj. Conf., Scottsdale, Arizona, I 53-I54.

Dollfus, P. \& JACOB-ChIA, D. (I974). Réflexions sur l'examen neurologique clinique en urgence du paraplégique. Ann. Méd. phys., 17, 513-519.

Dollfus, P., OtTinger, R., JACOB-ChiA, D. \& Adli, G. (I976). Réflexions sur l'examen neurologique clinique en urgence du tétraplégique. Ann. Méd. phys., 19, I74-I77.

Frankel, H. L., HANCOCK, D. O. \& Hyslop, G. (I969). The value of postural reduction in the initial management of closed injuries of the spine with paraplegia and tetraplegia. Part I. Paraplegia, 7, 179-192.

Frankel, H. L., Michaelis, L. \& Paeslack, V. (I973). Closed injuries of the cervical spine and spinal cord: results of conservative treatment of vertical compression injuries of the cervical spine with tetraplegia. Proc. 19th Veterans Adm. Spinal Cord Inj. Conf., Scottsdale, Arizona, 28-32.

Frankel, H. L., Michaelis, L. \& Paeslack, V. (1973). Closed injuries of the cervical spine and spinal cord: results of conservative treatment of extension rotation injuries of the cervical spine with tetraplegia. Proc. I9th Veterans Adm. Spinal Cord Inj. Conf., Scottsdale, Arizona, 52-55.

GutTMANN, Sir L. (1976). Spinal Cord Injuries. Comprehensive management and research. 2nd ed., Blackwell, Oxford.

HACHEN, H. J. (I977-78). Spinal cord injury in children and adolescents: diagnostic pitfalls and therapeutic considerations in the acute stage. Paraplegia, 15, 55-64.

HARDY, A. G. (I973). Management of paraplegia due to fracture-dislocations of the dorsolumbar junction. Proc. Igth Veterans Adm. Spinal Cord Inj. Conf., Scottsdale, Arizona, I 54-150.

MiChAELIS, L. S. (1969). International inquiry on neurological terminology and prognosis in paraplegia and tetraplegia. Paraplegia, 7, I-5.

Molé, J. P. (I977). Contribution à l'étude de la réanimation des tétraplégies traumatiques à la phase aiguë. Thesis, University of Strasbourg.

Paeslack, V., Frankel, H. L. \& Michaelis, L. (I973). Closed injuries of the cervical spine and spinal cord: results of conservative treatment of flexion fractures and flexion rotation fracture dislocation of the cervical spine with tetraplegia. Proc. I9th Veterans Adm. Spinal Cord Inj. Conf., Scottsdale, Arizona, 39-42.

STAUFFER, E. S. (I975). Diagnosis and prognosis of acute cervical spinal cord injury. Clin. Orthop., 112, 9-15.

Vlahovitch, B., FuENTES, J. M. \& Choucair, Y. (I975). Eléments de pronostique à la phase précoce des traumatismes vertébro-médullaires graves (valeur de la sensibilité à la douleur). Neuro-Chir. (Paris), 2I, 447-468.

Vlahovitch, B., FUENTES, J. M. \& CHOUCAIR, Y. (I977). Valeur pronostique indissociable des fonctions spinothalamique et corticospinale dans les traumatismes médullaires graves. Neuro-Chir. (Paris), 23, 55-72.

Young, J. S. \& DeXteR, W. R. (I978). Neurological recovery distal to the zone of injury in 172 cases of closed, traumatic spinal cord injury. Paraplegia, 16, 39-49.

ZaECH, G. A., SeIleR, W. \& Dollfus, P. (I976). Treatment results of spinal cord injuries in the Swiss Paraplegic Centre of Basle. Paraplegia, 14, 58-65. 